\title{
'It's Kinda Punishment': Tandem Logics and Penultimate Power in the Penal Voluntary Sector for Canadian Youth
}

\begin{abstract}
This paper draws on original empirical research in Ontario, Canada which analyses penal voluntary sector practice with youth in conflict with the law. I illustrate how youth penal voluntary sector practice (YPVS) operates alongside, or in tandem with the statutory criminal justice system. I argue that examining the PVS and the statutory criminal justice system simultaneously, or in tandem, provides fuller understandings of PVS inclusionary (and exclusionary) control practices (Tomczak and Thompson 2017). I introduce the concept of penultimate power, which demonstrates the ability of PVS workers to trigger criminal justice system response toward a young person in conflict with the law. My novel concepts of tandem logics and penultimate power are useful for understanding PVS practice, explaining how seemingly contradictory approaches across state and 'community' organizations not only co-exist, but depend upon the tandem relationship between the PVS and the statutory criminal justice system.
\end{abstract}

\section{Introduction}

This paper provides a global first examination of the youth penal voluntary sector and a fresh analysis of 'helping' penal power. It illustrates how the penal voluntary sector operates alongside, or in tandem with the statutory criminal justice system. I argue that examining the penal voluntary sector and the statutory criminal justice system simultaneously, or in tandem, provides fuller understandings of penal voluntary sector inclusionary (and exclusionary) control practices ${ }^{1}$. I introduce the concept of penultimate power, which demonstrates the ability of penal voluntary sector workers to trigger criminal justice system responses toward a young person in conflict with the law. My novel concepts of tandem logics and penultimate power are useful for understanding penal voluntary sector practice, explaining how seemingly contradictory approaches (e.g. inclusionary/exclusionary) across organizations (e.g. police and penal voluntary sector organizations) not only co-exist in youth justice, but are dependent upon the tandem relationship between the penal voluntary sector and the statutory criminal justice system. This paper draws on original empirical research in Ontario, Canada analysing YPVS practice. In Canada, youth justice legislation has federal jurisdiction and applies to 
youth between the ages of 12 and 18. I examine relationships between the penal voluntary sector and the criminal justice system and develop Valverde's (2010) examination of security logics by focusing on "how best to imagine shifting relations" (p.12) in dynamic penal projects. This article contributes to the emerging scholarship of the penal voluntary sector as an important site and actor in criminal justice systems around the world (see for example Tomczak and Buck, 2019; Corcoran et al., 2018) by examining the everyday practice of penal voluntary sector work which produces complex forms of inclusion and exclusion for youth in conflict with the law.

The penal voluntary sector refers to non-profit organizations that work at micro and macro levels with people, policies and issues that connect to the criminal justice system and crime (Tomczak, 2017). For example, on a micro level these organizations often work on a case management basis with those in conflict with the law and their families before, during and after their engagement with police, courts, probation and corrections elements of the criminal justice system. On a macro level, penal voluntary sector organizations might develop advocacy campaigns or research issues related to crime and the criminal justice system. In the contemporary penal voluntary sector in Canada, much of the programming for those in conflict with the law is classified into the mutually exclusive categories of men, women and youth. This article refers to the Youth Penal Voluntary Sector (YPVS) to refer to voluntary sector organizations which fall under the mandate of youth justice. The voluntary sector's role in responding to youth in conflict with the law in Canada predates the separate statutory youth justice system (Maurutto, 2003; Chen, 2005). From earlier ideas about needy children who require saving from negligent and poor families, to more modern notions of dangerous youth requiring risk-based interventions, governing approaches to children and youth have helped to shape notions of public and private responsibility (Tilton, 2010). Indeed, the creation of the juvenile delinquent was predicated on the recognition of adolescence as a separate category of personhood deserving of special public and private consideration (Ruddick, 2003). Examinations of 
the role of the voluntary sector are connected with the contested terrain regarding the role and function of government in society. That non-state actors, like the penal voluntary sector play a policing and punitive role to youth in conflict with the law, relates to debates and issues surrounding the state monopoly on crime control and/or the role of privatization in crime control (Garland, 2001). Furthermore, that the penal voluntary sector plays a role in exclusion challenges conceptions about the voluntary sector as playing a supportive and civic engagement role (Tomczak, 2017).

Enacted in 2003, Canada's current youth justice policy is the Youth Criminal Justice Act. This legislation has been described as a bifurcated youth justice policy (c.f. Minaker and Hogeveen, 2009:73), reflecting the criminal justice system's "bifurcation of control" (Rose, 2000; Garland, 2001). Innes (2003: 11) explains: "The socially included sections of society, when subject to censure for engaging in deviant acts, tend to be subject to reintegrative forms of control, whereas, individuals drawn from more economically and politically marginalized groups, are dealt with via means that serve to reinforce their exclusion”. The Youth Criminal Justice Act division of “young offenders into two groups of serious and minor also underlies an assumed division of responsibility between the state and the community in managing them" (Campbell, 2005:19 emphasis added). The community role is predominantly fulfilled by the YPVS. In the province of Ontario, the Ministry of the Attorney General and the Ministry of Child and Youth Services primarily undertake the responsibility to provide institutions and services to realize the principles and operations of the Youth Criminal Justice Act. The YPVS and other non-state actors are funded by these two ministries as transfer payments organizations "external to government to fund activities that benefit the public and are designed to achieve public policy objectives" (Government of Ontario, n.d.). The YPVS is significant, both in terms of the number of organizations that it is comprised of and proportions of the youth justice budget. The Ministry of Child and Youth Services funds approximately 200 organizations to achieve policy objectives from the Youth Criminal Justice Act. The funding of these 
programs comprises over half of the youth justice services budget in the province (Auditor General of Ontario, 2014).

The YPVS, like the adult PVS, is "enmeshed in the day-to-day operation of the criminal justice system" (Hucklesby and Corcoran, 2016: 1). For example, YPVS organizations (like Elizabeth Fry Society's-Marjorie Amos) operate open custody facilities which are often smaller and have less security features when compared to secure custody facilities (see also Gray and Salole, 2006). YPVS organizations, like the John Howard Society, play a supervisory and verification role for youth who do not have a surety before court appearances on the bail supervision program. YPVS organizations like Associated Youth divert youth from the statutory criminal justice system in programs called extra-judicial measures and extra-judicial sanctions. Larger YPVS organizations (like Springboard) often offer a range of youth justice programs and services alongside other programming not connected to the youth criminal justice system (e.g. housing for youth with developmental disabilities).

Criminologists continue to assess the impacts of Canada's Youth Criminal Justice Act and there remains no general consensus regarding assessments about the exclusionary effects of the policy (see for example Alain, Reid and Corrado, 2016; Smandych, Dyck, La Berge, and Koffman, 2016). While the youth crime rate was experiencing a decline in the late nineties, the Youth Criminal Justice Act, enacted in 2003, is sometimes attributed with reductions in the number of youth charged by the police and the per capita rate of custodial sentences (Bala and Carrington, 2015). Boyce (2015) for example observes that since the implementation of the Youth Criminal Justice Act "the rate of youth dealt with by other means has continued to be higher than the rate of youth formally charged, although this difference has been narrowing since 2009” (p. 22). In 2014, almost half $(48 \%)$ of accused youth were charged by police and processed through the statutory criminal justice system. The remaining 52\% were processed through other means including being warned or 
cautioned by police or referred to the YPVS. In the province of Ontario, custody admissions (a useful proxy data point for youth incarceration), declined by $72 \%$ between 2003 and 2014 and detention admissions declined by 33\% in the same period (Ministry of Children and Youth Services 2016). In contrast to jurisdictions like the state of Texas in the United States where the reduction of youth sent to state-run corrections institutions resulted in expansion of mass incarceration (Cate, 2016), Ontario's decrease in youth incarceration has resulted in the closure of both YPVS operated and state operated facilities. Most significantly, the Roy McMurtry Youth Center, the largest of Ontario's secure custody and detention facilities cited low incarceration rates as the primary reason for its slated closure as a youth facility (Minister of the Solicitor General 2016). Similarly, closures of open custody facilities, primarily operated by the YPVS, has resulted in the elimination of $68 \%$ of the beds available for youth in conflict with the law since 2003. Despite these closures, the Ministry of Children and Youth Services continue to be concerned about "excess capacity" (Ministry of Children and Youth Services 2016: p.11) and low "utilization rates" (Ministry of Children and Youth Services 2016: p.24) in youth custody facilities across the province.

Importantly, this trend toward less incarceration and an inclination to "define deviance down" (Garland 1996) has not been felt evenly for all youth in conflict with the law. In particular, Indigenous and Black youth continue to have high rates of incarceration. Malakieh (2018) shows Aboriginal youth made up $46 \%$ of admissions to correctional services in 2016-17 while making up only $8 \%$ of the youth population. A March 1, 2013 Toronto Star article reports that the proportion of jail admissions for Black youth is four times higher than when compared to the general young male population ${ }^{2}$. The trend of disproportionate representation of youth of colour is also relevant in other jurisdictions. In the United States, Black and Latino youth are disproportionately represented as criminal victims and offenders and are overrepresented in all aspects of the juvenile justice and criminal justice systems (Brame et al. 2014). Similarly more than half of the youth in prisons for 
young people in England and Wales are from a black and minority ethnic background (HM Inspectorate of Prisons, 2019). While there is a paucity of information about social demographics like race in the Canadian criminal justice system, there is far less information about the racial identity of people who are referred to the penal voluntary sector by statutory agencies. This is an important area of research deserving of further scholarship. In particular, data on legal factors (like types of offences) and extra-legal factors (like social demographics) that inform who is referred to the penal voluntary sector from statutory agencies could shape a better understanding of the inclusionary and/or exclusionary effects of the penal voluntary sector as well as the discretionary power of statutory agencies like the police, probation and the courts.

\section{Methodology}

This article is based on the findings of a broader research project that combines institutional ethnography (Smith 1987; 2005) and governmentality approaches (Foucault, 1991). Governmentality scholars recognize how 'discursive practices' of particular knowledges and how knowledge is applied to the social world. Considerations of logic or political rationalities examine “...the moral justifications for particular ways of exercising power by diverse authorities, notions of the appropriate forms, objects and limits of politics, and conceptions of the proper distribution of such tasks among secular, spiritual, military and familial sector” (Rose and Miller, 1992: 175). This recognition connects with Valverde's (2010) security framework which includes an analysis of the logic of projects. Valverde (ibid.) notes, "relations among different logics are complex, unpredictable and site-specific: an increase in the popularity or reach of one logic does not necessarily bring about a decline in another logic" (p.11). As such it is important to examine how different logics can and do co-exist. Smith's institutional ethnography $(1987 ; 2005)$ as both a theory and method for understanding social relations helped build methodological tools to understand how logics operate within an everyday lived experiences that are organized by social relations that are not 
observable within that reality. Given my interest in understanding how YPVS work is shaped by social relations, institutional ethnography is well suited to understanding work and in particular social service work (c.f. De Montigny, 1995; Ng, 1996; Nichols, 2014). Despite ontological and epistemological differences between Smith and Foucault, combining aspects of their methodologies is useful because of their respective contributions to understanding the relationship between power and knowledge (c.f. Satka and Skehill, 2012; Nichols, 2014).

I used multiple data points to build an understanding of how the YPVS works with/for/through the statutory criminal justice system. The YPVS programs discussed in this research are offered exclusively to youth in conflict with the law and do not necessarily represent the full spectrum of the penal voluntary sector, like policy advocacy programs (Tomczak, 2017). Twenty-four people were interviewed from a range of YPVS organizations and the statutory criminal justice system. Twenty respondents worked in the YPVS as paid employees, 2 were Police Officers and 2 were Probation Officers. Interviews were designed as an open-ended inquiry semi-structured by an interview guide. My focus was to gather detailed accounts of participants' work processes and also to better understand how they approached their work. Other data sources included field observations in courts and penal voluntary sector organizations, document collection (e.g. annual reports, youth intake forms, case notes), and a YPVS database generated from freedom of information requests.

This sample of YPVS workers involved those who receive a referral to work with youth in conflict with the law from the police, courts or probation. The title for this article, "it's kinda punishment" cites research participant Meredith $^{3}$, and reflects the lack of clarity surrounding the intention behind YPVS work. Specifically, the elision between helping and punishment results in, even YPVS workers, questioning their role in the criminal justice system. Frequency and contact between the YPVS and the statutory criminal justice system vary by program. A commonality across programs is that YPVS intervention with young people in conflict with the law is coordinated by the 
criminal justice procedure. For example, YPVS organizations are expected to provide the court and probation with summary reports of their work with youth in conflict with the law at court dates for youth in the bail supervision program or before their probation expires. That YPVS work is organized around the criminal justice system, instead of, for example, a young person's preference or progression in YPVS programming is an important orientation of YPVS work. There are important distinctions in the level of choice youth in conflict with the law experience in YPVS programs. For example, there is no element of choice in relation to carceral punishment and Attendance Centre sentences. Here, elements of 'choice' are limited to programming options or contrived choices, but the actual assignment of punishment is not a choice. Even within these mandated YPVS programs, assessments from YPVS workers can contribute to how youth are processed in the justice system. Importantly, more research is required on how penal voluntary sector work shapes decision making by police, courts and probation (Quirouette, 2017). An important theme in this article is that even YPVS workers are not confident about the impact they have on youth criminal justice system. There is, however, a case to be made that YPVS work influences criminal justice professionals like police, probation officers and judges. For example, if a YPVS worker employed in an open-custody facility determines that a young person was not compliant while serving their sentence and as a result wrote unfavourable assessments and reports about a young person these negative assessments could justify a more punitive or carceral response in the future.

YPVS programs like Bail Supervision programmes and Extrajudicial Measures programmes involve more opportunities for choice as youth choose to participate in these programs instead of a criminal justice sentence which could restrict their freedom more significantly. The choice of participation by the offender significantly "demarcates it from other forms of criminal justice intervention, where ordinarily offenders would have no such choice" (Thomas and Bull, 2013: p. 589). This arrangement, where penal voluntary sector workers receive a referral from the criminal 
justice system, is significant because it is a precursor to a dynamic where penal voluntary sector workers have the power to initiate further exclusionary effects by (re)involving police, courts or probation. This is the most coercive action penal voluntary sector workers can engage in with youth in conflict with the law and is discussed in subsequent sections.

\section{Tandem Logics}

While neither the YPVS nor the criminal justice system have a monopoly on any one logic, a division of labour exists between the two that is predicated on the YPVS employing a helping (or inclusionary) logic, and the criminal justice system a punitive (or exclusionary) logic. The arrangement where youth in conflict with the law are responded to by, first, the criminal justice system and, then, the YPVS marries the YPVS to the criminal justice system and creates a dynamic which invites comparison between the two entities. There is a tandem quality in the way the power relations in the criminal justice system and the YPVS are described as a result of the distinct division of labour and mandates. The notion of working in tandem recognizes that there is a certain level of acknowledgement of prominent logics by the YPVS and the criminal justice system. Here, the YPVS acknowledges that the criminal justice system is more punitive, and the criminal justice system recognizes that the YPVS has a more pronounced helping logic. As a result of this recognition, reified by criminal justice referrals to the YPVS (ostensibly for inclusion) and YPVS unsuccessful files being returned back to the criminal justice system (for exclusion), there is an interplay between the presumed dominant rationalities of the YPVS and the criminal justice system.

This duality leads to a false dichotomy and assumes inclusionary qualities of the YPVS (Tomczak and Thompson, 2017: p.16) while distorting the role of punishment in the YPVS. This observation that community involvement is falsely equated with treatment or rehabilitation is one widely observed by scholars of punishment (Armstrong, 2002; Garland, 2018; Hannah-Moffat and Maurutto, 2012; Miller, 2014). Studies documenting alternatives to custody document how 
community-based alternatives to the criminal justice system replicate punitive accountability approaches that are associated with prison. Similarly, Moore (2011) in an examination of drug treatment courts demonstrates that "benevolence and coercion can be two sides of the same coin" (p. 257). Following, Valverde's (2010) security framework, the question of how a helping logic can co-exist with more punitive logics in the YPVS work can be partially answered through an examination of how penultimate power operates in the YPVS. This dynamic between the YPVS and the criminal justice system contributes to the supposition of tandem logics between the YPVS and the criminal justice system.

\section{Penultimate Power}

YPVS workers in this investigation have the ability to initiate work sequences which would trigger a response from the criminal justice system toward a young person in conflict with the law (the YPVS client). The ability of YPVS workers to set in motion exclusionary effects is penultimate: YPVS workers report youth who are not meeting program expectations to police, courts and probation and ultimately it is the criminal justice system that proceeds with criminal charges and/or further entrenchment of young people with the criminal justice system. This once removed division of labour between the YPVS and the criminal justice system contributes to the tandem relationship because when the YPVS is the most exclusionary towards young people in conflict with the law, they are actually referring the young person back to the criminal justice system where the referral of the young person originates. Conversely, the statutory criminal justice system is ostensibly more inclusionary when police officers, probation officers and judges use their discretion to refer young people in conflict with the law to the YPVS rather than the statutory criminal justice system. Penultimate power is an important organizing feature for YPVS workers who, as my research demonstrates, purposefully explain and remind their youth clients that as a YPVS worker they have a communication channel with the statutory criminal justice system. Even when YPVS 
workers' exercise of their penultimate power resulted in outcomes like youth incarceration, YPVS workers often consider these activities as just one part of their overall position of 'helping' youth and therefore one incident which could be understood as exclusionary was not reflective of their overall 'helping' approach. A common sentiment shared was: By the very nature of the referrals from the criminal justice system, it is inevitable that a certain number of youth are going to continue to be entrenched in this system. Research participant Regina explained that youth referred to the YPVS, "are no angels" suggesting that there were limits to how much YPVS workers can protect youth from exclusionary effects. Regina's sentiment that not all youth referred to the YPVS will be helped or protected by the YPVS from exclusionary effects is an important one and shared by a number of YPVS research participants. For example, Shelley who has experience working as both a Probation Officer and in the YPVS, explains that the act of removing her youth client from the Bail Supervision program can be considered an act of care and one that is a consequence of the young person's actions and not hers.

I make it crystal clear to them how they would not succeed in the bail program, I say to them, if you do this, I'm gonna pull. If you do this, I'm gonna pull and then if I don't do it, what is that telling them? ....Toward the end of my days doing the bail program I was really clear that I was doing them a favour by pulling. I was doing them a favour because I am letting them feel the consequences of their actions ... A lot of these kids need to recognize that there are consequences to their actions. And that can be a huge life lesson for them. And as far as I'm concerned that is not even me doing that to them. I think this now as a Probation Officer. That is them doing the behavior that gets them breached, I'm just the messenger to the powers that be.

For Shelley, then, penultimate power can be configured as an act of care and evidence of a YPVS worker being responsible by playing the role of "messenger" to the criminal justice system, rather than colluder. Importantly, Shelley's relationship with youth is not the only factor which informs her decision making. Shelley also explained how it was important that the courts continue to trust Shelley and YPVS organizations to support young people to attend court dates as scheduled without 
additional charges. A second program example of penultimate power can be found in Extra-Judicial Sanctions where missed appointments with YPVS workers are often reflected in the completion letter to the Crown Attorney which summarizes youth participation and whether the extra-judicial sanction program has been completed. YPVS workers take care to explain the context for missed appointments, demeanor and behaviour while in YPVS programming and whether the program was successfully completed. Based on this communication, the Crown Attorney decides whether the young person has satisfied the requirements of the Extra-Judicial Sanction.

As alluded to by Shelley above, the exercise of YPVS penultimate power is often after a young person has been warned that such conduct would result in the YPVS worker reporting this conduct to the criminal justice system. This means that the coerciveness of statutory criminal justice agencies is ever-present (if even only in the shadows) of everyday YPVS work. In this way, the tandem arrangement between the YPVS and the criminal justice system is not sequential or oscillating between exclusionary and inclusionary. Rather, there is an ability for exclusionary and inclusionary practice to be present simultaneously while reconstituting each other (Gray and Salole, 2006). In addition, it is important to note that the YPVS can be disciplinary and punitive without using their penultimate power. Indeed, YPVS work includes incarceration, surveillance and correction, however, this more coercive nature of YPVS work is often obscured by the supposition that the sector is comparatively gentler and a "lesser harm" when compared to the statutory criminal justice system. Importantly, this "lesser than" claim can only be made in relation to the statutory criminal justice system.

The YPVS reporting conduct about youth clients not meeting their expectations to the criminal justice system, does not necessarily (nor reliably) result in the young person experiencing exclusionary effects - this decision ultimately lies with probation or the courts. For example, in this investigation YPVS worker Ray explained that while he is mostly in agreement when Probation 
Officers breach a young person for not following a probation order, he has been surprised when Probation Officers file charges unexpectedly ("I really thought he was going to give this kid another chance)". Conversely, YPVS worker Ray has also been surprised when Probation Officers did not breach a young person when Ray expected they would. Ray explains,

There's been a few times where I've been shocked, they didn't breach them. There was one kid who was impossible to control. Always picking fights with staff and other kids in group. He didn't listen to anyone and was a real terror. So, we don't tell probation right away about this stuff. We wait. We try to sort it out ourselves, but we could not get to this kid to even pretend he was paying attention to us. And he was really disruptive. And after this one day we'd all had it with him. And we told him, and we thought we would never see him again. And so, we did a case conference and we document everything about what this kid has done. We told this kids PO [Probation Officer] and then nothing. This kid was allowed to be completely out of control. He showed up to group next week like nothing happened.

A gap exists between YPVS workers personal judgment about what ought to happen to youth in conflict with the law and what actually happens in the criminal justice system. The size of this gap depends on a range of factors including, but not limited to, the quality of relationships between the YPVS and the criminal justice system and the structure of the YPVS program. This gap contributes to the level of faith or trust YPVS workers have in the criminal justice system and informs the way they understand and relate to their penultimate power. Ray's experience is an example of how some YPVS workers have a low level of authority about which youth attend their programming.

Importantly, other YPVS workers explained that they have built strong relationships with probation officers which results in a higher level of predictability. In the case of working with Probation Officers, the MCYS (2013) probation framework specifies "as the case manager, the Probation Officer receives information on all services and so is in a unique leadership position...” (p.10). This wording alludes to a tension regarding division of labour and responsibility between probation and the YPVS. 


\section{Coordinating and Managing Gaps}

Both YPVS workers and criminal justice workers explain how the distance between the YPVS and the criminal justice system is context specific and shifts to suit various purposes. First, the gap helps to differentiate the YPVS from the criminal justice system to their youth clients. Accordingly, YPVS workers manage the gap between YPVS organizations and the criminal justice system by accentuating the gap to clients in order to gain investment from young people about YPVS work. Donohue and Moore (2009) describe how constructing offenders into an active empowered client, "serves the very particular purpose of having people in conflict with the law buy into the interventions foisted upon them through the justice system” (p. 328). Similarly, YPVS workers interviewed for this research discussed how it is part of their work to demarcate their approach from the police, courts or probation that refer youth in conflict with the law to them (see also Tomczak, 2017). This demarcation is especially important in YPVS worker's communication with their youth clients. Arundeep explains how she uses a variety of "social work skills" in order to establish rapport and differentiate the YPVS from the criminal justice system in the intake session for her work at an Attendance Centre.

There is this pretty elaborate intake process. Youth sign forms about their rights and confidentiality and that's important for them to know about their rights but also we want them to know that something different is happening now. This is a new relationship between them and [the YPVS organization]....I have to get him to open up. I ask open-ended questions like: Why did the judge refer you to the program? And then I also ask relationship questions about a relationship they value. What do you think your Dad would like to see you achieve in this program? And that's how I hook them. I try to get them to see the judge referred them to me but that doesn't mean you or your family can't get something out of it too. It's really important that they value their time with me.

Arundeep explains that she is trying to establish that 'someone else' is mandating the young person to be referred to the YPVS and that the youth "may as well buy into the process" because there may be positive consequences of the young person's engagement in the YPVS. This client-based approach, 
prominent in social work and other 'helping professions', is tethered to a common power configuration in which the aim is to engage clients in a "democratic egalitarian manner" (Epstein 1999: p.8) to facilitate client change "without force, without command, indirectly. It must not be authoritative. It must enable its clients to be transformed, to adopt normative ways and thought voluntarily" (p.8). Thus, Arundeep communicates a wide gap between the YPVS and the criminal justice system because it further aligns Arundeep with inclusionary practice.

Criminal justice workers also recognized that the gap between their work and the PVS has value. Nevon, a Police Officer, describes, "they (PVS workers) are able to take the time, where we really can't" (Nevon, Police Officer) and "NGO’s (non-governmental organizations] are able to go the extra mile" (Frank, Probation Officer). Further, it was noted how the coercive nature of the criminal justice system undermines their ability to forge relationships with youth. Research respondent Greg explained that as a Police Officer he can,

..put certain demands on people. So a lot of my conversations with young people are not voluntary. That changes everything. No matter what people are not going to think that I really just care about young people. I don't think that's why people get into this work. If that's what people wanted to do -they wanted to care - they wanted to do social development, they wouldn't be a Police Officer. We might have exceptional days but it's not part of our job description.

Here, Greg suggests that the there are limits to the degree he is able to be perceived as inclusionary because of the nature of policing work. Greg also suggested that as a result of the priority placed on the exclusionary role of policing, referring youth to the YPVS is more inclusionary because "they [YPVS] can do it better".

More than contentions about mandates surrounding inclusionary and exclusionary effects, there are also constraints surrounding how much time the traditional criminal system has to spend with youth in conflict with the law in order to be inclusionary. Indeed, the time and care offered by the YPVS works in tandem with the quickness and terseness offered by the criminal justice system. 
This "good cop/bad cop" arrangement was presented as functional by a number of the research participants. YPVS worker Carlos explained that being aware of this dynamic was an important part of his position as a residential counsellor for young people in custody.

By the time they [young people in conflict with the law] come here, by the time they see me. They have usually had a lot people yell at them, get angry and well, they've burnt a lot of bridges. And so, I can't do the same. Not only do I know that getting tough on them is not what they need right now, I am essentially living with these guys and being a parent to them and to be tough with them isn't really sustainable. I can't be that tough guy 8 hours a day. Police can do that. They just spend a couple hours with them. I need to build a relationship with them.

As noted by Carlos this governance arrangement also has temporal consequences where YPVS engagement with young people is longer and more intimate than police engagement with youth.

The tandem arrangement and gap between the criminal justice system and the YPVS also helps to create a filter so that criminal justice workers, like Probation Officers, are not always privy to case management information understood as superfluous. For example, Probation Officer research participant Frank indicated: “I don't want them [YPVS workers] calling me every time they [young people in conflict with the law] don't show up for an appointment. They help to minimize the minutiae". For Frank, YPVS programming helps him to focus on more important tasks like the overall management of his caseload. It is important to note that as a Probation Officer, Frank never loses the ability acquire information from the YPVS and he could decide that there are some young people with whom he would like to know the minutiae: when and how many YPVS appointments they miss.

Unlike popular representations of the "good cop/bad cop" dynamic, the YPVS is not necessarily colluding with the criminal justice system. Indeed, the considerable gaps and low levels of coordination between the YPVS and the criminal justice system mean YPVS workers can be uncertain about how (and whether) their penultimate power will be responded to by statutory 
agencies. For some of those working with young people in conflict with the law, like Arundeep, the gap between the criminal justice system and the YPVS creates and opportunities to assign new and different meanings to their work. For other YPVS workers, the lack of coordination can undermine their authority over their work.

\section{CONCLUSION}

The Youth Criminal Justice Act "has re-authorized and re-responsibilized communities, via publicly funded community-based agencies and services" (Mann et al. 2007). This shift makes the role of the YPVS in the youth criminal justice system even more significant and important to examine. As scholars turn to analyse the penal voluntary sector, it is important to consider how the penal voluntary sector and YPVS work with the criminal justice system. This article examined governance practices in YPVS organizations in their youth justice work and specifically considered how seemingly contradictory logics like 'helping' and punitiveness can co-exist in the YPVS. The partnership between the criminal justice system and the YPVS to deliver youth justice services structures a dynamic between the two entities which invites comparison. Here, the YPVS is positioned as the gentler response to youth in conflict with the law because they do not have the same powers and mandate as the criminal justice system. While neither the YPVS nor the criminal justice system have singular governing approach, a division of labour exists between the two that is predicated on the YPVS employing a helping logic, and the criminal justice system a punitive logic. The penultimate power in the YPVS and the distance between the YPVS and the criminal justice system contributes to the supposition of tandem logics. Examining the criminal justice system and the YPVS simultaneously helps to build a better understanding of how different approaches and logics can coexist. 


\section{REFERENCES}

Alain, M, Reid, S. and Corrado, R. (2016). Implementing and working with the Youth Criminal Justice Act across Canada. Toronto: University of Toronto Press.

Armstrong, S. (2002). "Punishing not for profit: Implications of nonprofit privatization in juevenile punishment', Punishment and Society, 4/3:345-368.

Auditor General of Ontario. (2014). Youth justice services program follow-up. Retrieved from: http://www.auditor.on.ca/en/reports en/en14/412en14.pdf

Bala, Nicholas, and Peter J. Carrington. 2015. "The changing nature of youth justice: Impact of the Youth Criminal Justice Act”. Pp. 265-277 in J.V. Roberts and M.G. Grossman (eds.), Criminal Justice in Canada. 5th ed. Toronto: Nelson.

Boyce, J. (2015) Police-reported crime statistics in Canada, 2014. Juristat: Statistics Canada Catalogue no. 85-002-X.

Brame, R., S. D. Bushway, R. Paternoster, and M. G. Turner. (2014). "Demographic Patterns of Cumulative Arrest Prevalence by Ages 18 and 23." Crime and Delinquency: 1-6.

Campbell, K. (2005). Introduction: Theoretical overview. In K. Campbell (Ed.), Understanding Youth Justice in Canada. (pp.1-19). Toronto, ON: Pearson Education. 
Cate, S. (2016). Devolution, not decarceration: 'The limits of juvenile justice reform in Texas'. Punishment and Society 18/5 578-609.

Chen, X. (2005). Tending the gardens of citizenship: Child saving in Toronto, 1880s-1920s. Toronto, ON: University of Toronto.

Corcoran, M. Williams, K., Prince, K. , and Maguire, M. (2018), 'The Penal Voluntary Sector in England and Wales: Adaptation to Unsettlement and Austerity', The Political Quarterly, 89/2. 187196.

De Montigny, G. A.J. (1995) Social Working: An Ethnography of Front-Line Practice. Toronto: University of Toronto Press.

Donohue, E and Moore, D. (2009). "When is an offender not an offender? Power, the client and shifting penal subjectivities. Punishment \& Society 11(3) 319-336.

Foucault, M. (1991).'Governmentality'. The Foucault Effect - Studies in governmentality. G. Burchell, C. Gordon, and P. Miller (Ed.). Chicago: University of Chicago Press.

Garland, D. (1996). The limits of the sovereign state: Strategies of crime control in contemporary society. British Journal of Criminology, 36: 445-71.

Garland, D. (2001) The Culture of Control. Oxford: Oxford University Press. 
Garland. D. (2018). 'Theoretical advances and problems in the sociology of punishment', Punishment and Society, 201/1: 8-33.

Gray, G., and Salole, A. (2006). “The Local Culture of Punishment: An Ethnography of Criminal Justice Worker Discourse," The British Journal of Criminology 46 (4): 661-679.

Hannah-Moffat K. and Maurutto, P. (2012) 'Shifting and targeted forms of penal governance: Bail, Punishment and specialized courts', Theoretical Criminology, 16/2: 201-219

HM Inspectorate of Prisons (2019). Children in Custody 2017-18: An analysis of 12-18-year-olds' perceptions of their experiences in secure training centres and young offender institutions. Accessed from: https://www.justiceinspectorates.gov.uk/hmiprisons/wpcontent/uploads/sites/4/2019/01/6.5164_HMI_Children-in-Custody-2017-18_A4_v10_web.pdf

Hucklesby A., and Corcoran M. (2016) Introduction. In: Hucklesby A., Corcoran M. (eds) The Voluntary Sector and Criminal Justice. Palgrave Macmillan, London.

Innes, M. (2003). Understanding Social Control: Deviance, Crime and Social Order. Maidenhead: Open University Press.

Malakieh, J. (2018). Adult and youth correctional statistics in Canada, 2016/2017. Juristat. Statistics Canada.

Mann, R. M., Senn, C. Y., Girard, A., \& Ackbar, S. (2007). Community-based interventions for atrisk youth in Ontario under Canada's youth criminal justice act: A case study of a "runaway" girl. 
Canadian Journal of Criminology and Criminal Justice/Revue Canadienne De Criminologie Et De Justice Penale, 49(1), 37-74.

Maurutto, P. (2003). Governing charities: Church and state in Toronto's catholic archdiocese, 1850-1950.

Montreal, QC: McGill-Queens University Press.

Ministry of Community Safety and Correctional Services (November 2016).

Ministry of Children and Youth Services (2013). Probation Framework. Queens Printer.

Miller, R. J. (2014), 'Devolving the carceral state: Race, prisoner reentry and the micro-politics of urban poverty management', Punishment and Society. 16/3: 305-335.

Minkaer, J. and Hogeveen, B. (2009). Youth, Crime and Society. Toronto: Pearson.

Moore, Dawn. (2011). "The Benevolent Watch: Therapeutic Surveillance and Drug Treatment Courts." Theoretical Criminology. 15(3) 255-268.

Ng, R. (1996). The Politics of Community Services: Immigrant Women, Class and State. 2nd ed. Halifax: Fernwood.

Nichols, N. (2014.) Youth Work: An institutional ethnography of youth homelessness. Toronto: The University of Toronto Press. 
Owusu-Bempah, A. and Wortley, S. (2013). Race, crime and criminal justice in Canada. In S. Bucerius and M. Tonry (eds.) The Oxford Handbook of Ethnicity, Crime and Immigration. Oxford University Press.

Quirouette, M. (2018), 'Community Practitioners in Criminal Courts: Risk Logics and MultiplyDisadvantaged Individuals', Theoretical Criminology, 22: 582-602.

Rankin, J. \& Winsa, P. (2013, March 1). Unequal justice: Aboriginal and black inmates disproportionately fill Ontario jails. Toronto Star. Retrieved from http://www.thestar.com/news/insight/2013/03/01/unequal justice aboriginal and black inmate $\underline{\text { s disproportionately fill ontario jails.html }}$

Rose, N. (2000). “Government and Control.” British Journal of Criminology 40(2): 321-39.

Rose, N. and P. Miller (1992) 'Political Power Beyond the State: Problematics of Government', The British Journal of Sociology 43(2): 172-205.

Ruddick, S. (2003). The Politics of Aging: Globalization and the Restructuring of Youth and Childhood. Antipode 35(2): 334-62.

Satka, M. E. \& Skehill, C. (2012). Michel Foucault and Dorothy Smith in case file research: Strange bed-fellows or complementary thinkers? Qualitative Social Work 11(2), 191-205.

Smandych, R. Dyck, M, La Berge, C., and Koffman. J. (2016). Youth Justice in Manitoba: Developments and issues under the YCJA. In M. Alain, R. Corrado and S. Reid (Eds.) Implementing and working with the Youth Criminal Justice Act across Canada. Toronto: University of Toronto Press.

Smith, D. E. (1987). The Everyday World as Problematic: A Feminist Sociology. Toronto: University of Toronto Press. 
Smith, D. (2005). Institutional Ethnography: A Sociology for People. Toronto: AltaMira Press.

Thomas, N., \& Bull, M. (2013). Negotiating the challenges of coerced treatment: An exploratory study of community-based service providers in Queensland, Australia. Contemporary Drug Problems, 40(4), 569-594.

Tilton, J. (2010). Dangerous or Endangered?: Race and the Politics of Youth in Urban America. New York: New York University Press.

Tomczak, P. (2017). The Penal Voluntary Sector. Abingdon: Routledge.

Tomczak, P. and Thompson, P. (2017) Inclusionary control? Theorizing the effects of penal voluntary organizations’ work. Theoretical Criminology 1-21.

Tomczak, P and Buck, G. (2019) The penal voluntary sector: a hybrid sociology. British Journal of Criminology 1-21.

Valverde, M. (2010). Questions of security: A framework for research. Theoretical Criminology 15(1)322.

1 Tomczak and Thompson (2017) write how PVS organizations deploy 'inclusionary control' which can be both inclusionary (providing objective or subjective improvement for those in conflict with the law) and exclusionary (negative controlling effects which bolster penal control and exclusion) "albeit constrained by the carceral net" (p. 5). 
2 There is little official Canadian data on race and criminal activity and criminal justice procedure because it is not collected and/or not released (see Owusu-Bempah and Wortley, 2013)

${ }^{3}$ Pseudonyms were used in this article. 